\title{
Pengaruh profitabilitas, likuiditas, dan struktur modal terhadap deviden payout ratio
}

\author{
1*Hany Nurwahyu Muslimah Ara'Afi \\ ${ }^{I}$ Fakultas Ekonomi, Universitas Sarjanawiyata Tamansiswa, Jalan Kusumanegara Yogyakarta 55165 \\ *e-mail korespondensi: hanyaraafi0@gmail.com
}

\begin{tabular}{l|l}
\hline \hline \multicolumn{1}{c}{ Keywords } & \multicolumn{1}{c}{ Abstract } \\
\hline \hline profitability, & The purpose of this study is to describe (1) Analysis of Profitability on Dividend \\
liquidity, capital & Payout Ratio in Real Estate companies in the period 2013-2017. (2) Effect of \\
payout ratio & Liquidity on the Dividend Payout Ratio for Real Estate companies in the period \\
& 2013-2017. (3) Effect of Capital Structure on Dividend Payout Ratio on Real Estate \\
& companies for the period 2013-2017. The sample of this study was 11 companies \\
& selected using the purposive sampling method. Data analysis is multiple linear \\
& regression to identify independent variables that affect the dependent variable. The \\
& results showed that (1) profitability does not effect Dividend Payout Ratio. (2) \\
& liquidity does not effect Dividend Payout Ratio. (3) capital structure has a positive \\
& significant effect on the Dividend Payout Ratio. (4) profitability, liquidity, and \\
& capital structure simultaneously influence dividend Payout Ratio.
\end{tabular}

\begin{tabular}{|c|c|}
\hline Kata Kunci & Abstrak \\
\hline $\begin{array}{l}\text { profitabilitas, } \\
\text { likuiditas, struktur } \\
\text { modal, rasio } \\
\text { pembayaran } \\
\text { dividen }\end{array}$ & $\begin{array}{l}\text { Tujuan penelitian ini adalah untuk mendeskripsikan (1) Analisis Profitabilitas } \\
\text { terhadap Dividend Payout Ratio pada perusahaan Real Estate periode 2013-2017. } \\
\text { (2) Pengaruh Likuiditas terhadap Dividend Payout Ratio pada perusahaan Real } \\
\text { Estate periode 2013-2017. (3) Pengaruh Struktur Modal terhadap Dividend Payout } \\
\text { Ratio pada perusahaan Real Estate periode 2013-2017. Sampel penelitian ini adalah } \\
11 \text { perusahaan yang dipilih dengan menggunakan metode purposive sampling. } \\
\text { Analisis data adalah regresi linier berganda untuk mengidentifikasi variabel } \\
\text { independen yang mempengaruhi variabel dependen. Hasil penelitian menunjukkan } \\
\text { bahwa (1) profitabilitas tidak berpengaruh terhadap Dividend Payout Ratio. (2) } \\
\text { Likuiditas tidak mempengaruhi Rasio Pembayaran Dividen. (3) Struktur modal } \\
\text { berpengaruh positif signifikan terhadap Dividend Payout Ratio. (4) profitabilitas, } \\
\text { likuiditas, dan struktur modal berpengaruh secara simultan terhadap rasio } \\
\text { pembayaran dividen. }\end{array}$ \\
\hline
\end{tabular}

\section{PENDAHULUAN}

Salah satu tujuan yang diharapkan untuk oleh suatu perusahaan adalah meningkatkan kesejahteraan dan mensejahterakan pemegang saham melalui menungkatnya nilai perusahaan. Peningkatan nilai perusahaan dapat dicapai jika perusahaan mampu beroperasi dan mencapai laba yang telah ditentukan (Puspaningsih \& Pratiwi, 2017). Melalui laba yang diperoleh, perusahaan mampu membagikan dividen kepada para pemegang saham, 
meningkatkan perkembangan perusahaan dan mempertahankan keberlangsungan perusahaan. Kebijakan pembayaran dividen mempunyai pengaruh bagi pemegang saham dan perusahaan yang membayar dividen. Para pemegang saham menginginkan pembagian dividend yang stabil hal tersebut akan mengurangi ketidakpastian akan hasil yang diharapkan dari investasi yang mereka lakukan dan juga dapat meningkatkan kepercayaan pemegang saham terhadap perusahaan sehingga nilai saham juga dapat meningkat. Jika perusahaan, memilih untuk membagikan laba dalam bentuk deviden maka pembagian tersebut akan akan mengurangi sumber dana dari dalamnya, sebaliknya jika perusahaan membuat keputusan untuk menahan labanya dalam bentuk laba ditahan maka dana internalnyayang di dapat akan semakin tinggi yang dapat digunakan untuk membiayai perkembangan perusahaan sehingga mengurangi ketergantungan perusahaan terhadap dana hutang.

Manajemen harus memperhatikan kepentingan perusahaan dan kepentingan pemegang saham, sehingga pihak manajemen dapat mengambil keputusan kebijakan dividen yang optimal yang dapat memaksimalkan nilai perusahaan (Kusuma, 2018). Untuk mengukur tingkat keuntungan suatu perusahaan diantaranya, digunakan rasio profitabilitas yang dikenal di proxikan dengan rasio rentabilitas. Profitabilitas perusahaan adalah kemampuan perusahaan mendapatkan laba, laba yang didapat berhubungan dengan penjualan, total aset maupun modal sendiri. Profitabilitas dalam penelitian dini di proxikan dengan return on asset. Likuiditas perusahaan adalah faktor penting bagi perusahaan yang harus dipertimbangkan dalam mengambil keputusan untuk menetapkan besarnya dividen yang akan dibayarkan pada pemegang saham. Rasio dalam penelitian ini di-proxy-kan dengan Current Ratio, semakin tingggi tingkat Current Ratio dalam perusahaan semakin besar juga kemampuan perusahaan dalam memenuhi kewajiban jangka pendek, diantaranya dapat membayar dividen.

Untuk membagikan dividen perusahaan harus terlebih dahulu membayar kewajiban yaitu hutang, semakin besar hutang yang harus dibayar, semakin kecil dana yang dapat dibagikan sebagai dividen. Dengan demikian struktur modal juga mempengaruhi pembagian dividen. Struktur modal di proxikan dengan Debt to Equity Ratio (DER). Pemakaian proxy dimaksudkan untuk mempermudah pengukuran karena faktor tersebut tidak dapat diukur secara langsung.

\section{TEORI \& HIPOTESIS}

\section{Profitabilitas}

Profitabilitas perusahaan merupakan kemampuan perusahaan memperoleh laba dalam hubungannya dengan penjualan, total aset maupun modal sendiri. tingkat profitabilitas yang baik akan mendorong para investor untuk melakukan investasi kedalam perusahaan tersebut. Dengan demikian bagi investor jangka panjang akan sangat penting menggunakan analisis profitabilitas untuk melihat laba yang diterima dalam bentuk dividen (Anggraini, 2013).

Dalam penelitian ini profitabillitas akan diukur dengan Return On Asset (ROA). Kasmir (2012) menyatakan bahwa Return on Assets (ROA) mengukur kemampuan perusahaan dalam memanfaatkan aktivanya untuk memperoleh laba. Return on Asset (ROA) 
menunjukkan kemampuan perusahaan untuk menghasilkan laba dari aktiva yang digunakan.

\author{
Return on Asset $=$ \\ Laba Setelah Bunga dan Pajak $\times 100 \%=\ldots . . \%$ \\ Total Aset
}

\title{
Likuiditas
}

Menurut Harahap (2009) likuiditas merupakan rasio yang mengukur kemampuan perusahaan memenuhi kewajiban jangka pendeknya berupa hutang, biaya kegiatan operasional, dan pembayaran dividen. Likuiditas perusahaan diasumsikan mampu menjadi alat prediksi tingkat pengembalian investasi berupa dividen bagi investor. Current ratio seringkali dijadikan sebagai ukuran likuiditas (Asril, 2009)

Menurut (Syamsuddin, 2009), "likuiditas tidak hanya berkenaan dengan keadaan keseluruhan keuangan perusahaan, tetapi juga berkenaan dengan kemampuannya untuk mengubah aktiva lancar tertentu menjadi uang kas". Perusahaan harus mengubah aktiva lancar tertentu menjadi kas untuk membayar kewajiban lancarnya, misalnya perusahaan perlu menagih piutang atau menjual persediaannya sehingga perusahaan memperoleh kas untuk membayar hutang, kegiatan operasional dan membayar dividen.

Current Ratio $=$

Current Assets $\times 100 \%=\ldots \%$

Current Liabilities

\section{Struktur Modal}

Struktur modal erat kaitannya dengan keputusan pendanaan yang dilakukan perusahaan. Pemilihan sumber dana dapat berasal dari dalam maupun luar. Sumber dana internal perusahaan dapat berasal dari laba ditahan dan depresiasi, sedangkan sumber dana eksternal perusahaan berasal dari hutang untuk menambah asset operasi. Pemilihan struktur modal yang pada akhirnya juga menentukan berapa banyak hutang yang akan digunakan perusahaan untuk mendanai aktivanya.

Penggunaan hutang akan menyebabkan adanya pengeluaran untuk membayar bunga, semakin besar hutang berarti semakin besar biaya bunga yang harus ditanggung oleh perusahaan sehingga akan menyebabkan laba setelah bunga menurun. Keputusan pendanaan atau permodalan serta keputusan pengelolaan asset harus diambil dengan tetap berpedomankan pada tujuan untuk memaksimalkan nilai perusahaan.

Dalam penelitian ini struktur modal akan diukur menggunakan Debt to Equity Ratio (DER). Menurut Harahap (2009), "Debt to equity ratio merupakan rasio yang menggambarkan sampai sejauh mana modal pemilik dapat menutupi utang - utang kepada pihak luar. Semakin kecil rasio ini semakin baik".

$D E R=\frac{\text { Total Debt }}{\text { Total Equity }}=\ldots \%$ 


\section{Dividend Payout Ratio}

Kebijakan dividend adalah keputusan mengenai apakah laba akan dibagikan kepada pemegang saham atau akan ditahan untuk pembiayaan investasi dimasa datang (Sartono, 2010). Besar kecilnya deviden yang dibayarkan kepada pemegang saham tergantung dari kebijakan masing-masing perusahaan yang ditentukan dalam Rapat Umum Pemegang Saham (RUPS). Rasio pembayaran dividen (dividend payout ratio) menentukan jumlah laba yang dapat ditahan sebagai sumber pendanaan. Semakin besar laba ditahan semakin sedikit jumlah laba yang dialokasikan untuk pembayaran dividen (Kusuma, 2018).

Dividend Payout Ratio (DPR) adalah rasio yang melihat bagian pendapatan dari perusahaan yang dibayarkan kepada para pemegang saham dalam bentuk dividen yang dihitung dengan membagi dividen per lembar saham dengan pendapatan per lembar saham (Harahap, 2009).

\section{Return on Asset terhadap Dividend Payout Ratio}

Pihak manajemen akan membayarkan dividen untuk memberikan sinyal mengenai keberhasilan perusahaan dalam menghasilkan profit. Semakin besar profit yang diperoleh maka akan semakin besar pula kemampuan perusahaan untuk membayar dividen. Dengan demikian profitabilitas mutlak diperlukan untuk perusahaan apabila akan membayar dividen.

Profitabilitas adalah tingkat laba bersih yang berhasil diperoleh perusahaan dalam menjalankan operasionalnya. Dividen merupakan bagian dari laba bersih perusahaan yang dibagikan kepada pemegang saham, oleh karenanya dividen akan dibagikan jika perusahaan memperoleh laba. Laba yang layak dibagikan kepada para pemegang saham, adalah laba setelah perusahaan memenuhi seluruh kewajiban tetapnya yaitu beban bunga dan pajak. Karena dividen diambil dari laba bersih yang diperoleh perusahaan, maka laba tersebut akan mempengaruhi besarnya Dividend Payout Ratio.

$\mathrm{H}_{1}$ : Return on Asset berpengaruh positif terhadap Dividend Payout Ratio

\section{Current Ratio terhadap Dividend Payout Ratio}

Likuiditas (Current Ratio) mempengaruhi kebijakan dividen dikarenakan likuiditas merupakan kemampuan perusahaan untuk memenuhi kewajiban jangka pendek. Current Ratio suatu perusahaan merupakan faktor penting yang harus dipertimbangkan sebelum perusahaan mengambil keputusan untuk menetapkan besarnya dividen yang akan dibayarkan kepada para pemegang saham. Dividen bagi perusahaan merupakan arus kas keluar, maka semakin besar posisi kas dan likuiditas (Current Ratio) perusahaan secara keseluruhan akan semakin besar kemampuan perusahaan untuk membayar dividen (Anggraini, 2013).

Current Ratio bagus belum tentu baik. Baik atau tidaknya tergantung untuk keperluan apa. Jika dilihat dari keperluan untuk pengaruh current ratio terhadap dividend payout ratio maka perusahaan mempunyai kewajiban untuk membayar dividen. Untuk membagi dividen diperlukan kas yang cukup. Current ratio tinggi belum tentu perusahaan dapat membayar 
dividen kepada investor hal tersebut disebabkan karena komposisi aktiva lancar lebih banyak di persediaan atau piutang.

$\mathrm{H}_{2}$ : Current Ratio berpengaruh positif terhadap Dividend Payout Ratio

\section{Debt to Equity Ratio terhadap Dividend Payout Ratio}

Seberapa besar laba yang dibagi tergantung pada kebutuhan dana, jika perusahaan menambah dana dengan hutang untuk perkembangan perusahaan maka laba yang dibagi sebagai dividen (DER) naik sehingga (DPR) juga naik.

Jika tambahan dana diambil dari laba berarti menggunakan modal sendiri sehingga laba yang di bagi akan turun, (DER) turun maka (DPR) juga menurun. Dari uraian diatas maka terdapat pengaruh positif (DER) terhadap (DPR).

$\mathrm{H}_{3}$ : Debt to Equity Ratio berpengaruh positif terhadap Dividend Payout Ratio

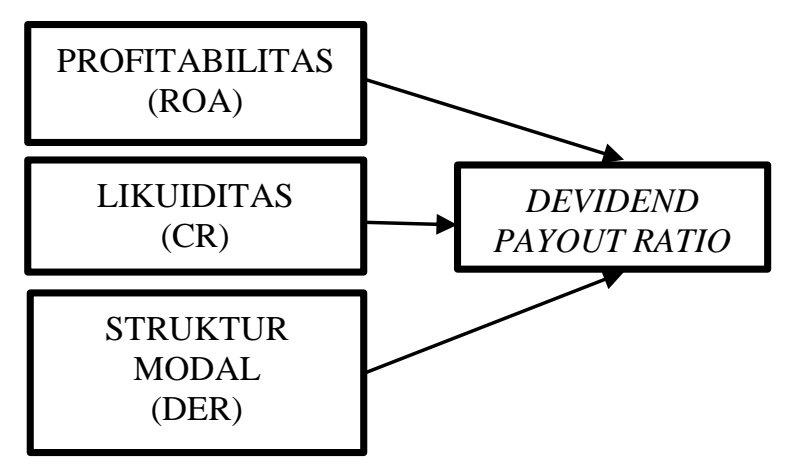

Gambar 1. Kerangka Konseptual

\section{METODE PENELITIAN}

Penelitian yang dilakukan penulis bersifat penelitian kuantitatif dengan menggunakan pendekatan penelitian korelasional (corelational reseach). Penelitian korelasional adalah tipe penelitian deengan karakteristik masalah berupa pengaruh antara dua variabel atau lebih dengan tujuan untuk melihat ada atau tidaknya hubungan antara variabel satu dengan variabel lainnya. Pada penelitian ini terdapat dua variabel yaitu variabel terikat (dependen) dan variabel bebas (independen). Variabel terikat (Y) adalah Dividend Payout Ratio (DPR), sedangkan variabel bebas (X) terdiri dari Profitabilitas (ROA), likuiditas (CR), struktur modal (DER).

Menurut Harahap (2009), profitabilitas perusahaan merupakan kemampuan perusahaan memperoleh laba dalam huubungannya dengan penjualan, total aktiva maupun modal sendiri.

$R O A=\underline{\text { Laba Setelah Bunga \& Pajak }}$

Total Aset 
Menurut Harahap (2009), Current Ratio merupakan rasio yang mengukur kemampuan perusahaan memenuhi kewajiban jangka pendeknya.

\section{$C R=\underline{\text { Aset Lancar }}$ \\ Hutang Lancar}

Menurut Harahap (2009), Debt to equity ratio merupakan rasio yang menggambarkan sampai sejauh mana modal pemilik dapat menutupi utang- utang kepada pihak luar.

\section{$D E R=\frac{\text { Total Debt }}{\text { Total Equity }}$}

Menurut Harahap (2009), Dividend Payout Ratio (DPR) adalah rasio yang melihat bagian pendapatan dari perusahaan yang dibayarkan kepada para pemegang saham dalam bentuk dividen yang dihitung dengan membagi dividen per lembar saham dengan pendapatan per lembar saham.

\section{Dividend Payout Ratio $=\underline{\text { Dividend Per Share }}$ Earning Per Share}

Populasi yang ada dalam penelitian ini adalah 60 perusahaan real estate yang terdaftar dalam Bursa Efek indonesia. Dalam pengambilan sampel untuk penelitian ini dilakukan dengan metode purposive sampling. Purposive sampling merupakan teknik pengambilan sampel secara sengaja dengan pertimbangan tertentu.

Pertimbangan yang digunakan peneliti dalam mengambil sampel yaitu: 1) perusahaan yang terdaftar dalam Bursa Efek Indonesia yang masuk dalam sektor real estate yang menerbitkan laporan keuangan selama periode penelitian, 2) perusahaan yang membagikan dividen secara berturut-turut selama periode penelitian, 3) perusahaan yang tidak mengalami kerugian selama periode penelitian. Menggunakan teknik purposive sampling terdapat 11 sampel perusahaan real estate yang masuk dalam kriteria.

\section{HASIL DAN PEMBAHASAN}

Penelitian ini adalah untuk melihat apakah terdapat pengaruh antara variabel independen terhadap Divident Payout Ratio (DPR). Dari analisis menggunakan SPSS versi 16. Berdasarkan pengujian yang telah dilakukan pada penelitian ini dapat dinyatakan data dalam penelitian lolos dalam pengujian asumsi klasik yang diantaranya yaitu uji normalitas, uji linearitas, uji multikolinearitas, uji heteroskedastisitas, dan Uji Autokorelasi. 
Tabel 1

Regresi Linier Berganda (Uji F)

ANOVA $^{\mathrm{b}}$

\begin{tabular}{ccccccc}
\hline & Model & Sum of Squares & Df & Mean Square & F & Sig. \\
\hline 1 & Regression & 725.282 & 3 & 241.761 & 1.584 & $.205^{\mathrm{a}}$ \\
& Residual & 7786.286 & 51 & 152.672 & & \\
& Total & 8511.568 & 54 & & & \\
\hline
\end{tabular}

a. Predictors: (Constant), ROA, CR, DER

b. Dependent Variable: DPR

Berdasarkan Tabel 1 diketahui bahwa nilai signifikansi=0.205. Berdasarkan hasil penelitian ini dapat diketahui bahwa 0.205>0.05 yang berarti sesuai dengan dasar pengambilan keputuan Ha akan diterima jika probabilitas lebih dari 0.05 dan h0 ditolak. Hal ini dapat disimpulkan bahwa return on asset, current ratio dan debt to equity ratio secara bersama-sama berpengaruh secara simultan terhadap dividend payout ratio. Sehingga hipotesis pertama diterima dan terbukti.

Tabel 2

Regresi Linier Berganda (Uji t)

\begin{tabular}{|c|c|c|c|c|c|c|}
\hline \multicolumn{7}{|c|}{ Coefficients } \\
\hline & \multirow[t]{2}{*}{ Model } & \multicolumn{2}{|c|}{$\begin{array}{l}\text { Unstandardized } \\
\text { Coefficients }\end{array}$} & \multirow{2}{*}{$\begin{array}{l}\text { Standardized } \\
\text { Coefficients } \\
\text { Beta }\end{array}$} & \multirow[t]{2}{*}{$\mathrm{T}$} & \multirow[t]{2}{*}{ Sig. } \\
\hline & & B & Std. Error & & & \\
\hline \multirow[t]{4}{*}{1} & (Constant) & 20.650 & 6.347 & & 3.254 & .002 \\
\hline & ROA & .020 & .150 & .018 & .131 & .896 \\
\hline & CR & .017 & .018 & .129 & .932 & .356 \\
\hline & DER & 8.886 & 4.211 & .289 & 2.110 & .040 \\
\hline
\end{tabular}

a. Dependent Variable: DPR

Dari tabel di atas dapat disusun persamaan sebagai berikut:

$$
\text { Prediksi DPR }=20,650+0,020 \mathrm{ROA}+0,017 \mathrm{CR}+8,886 \mathrm{DER}+\mathrm{e}
$$

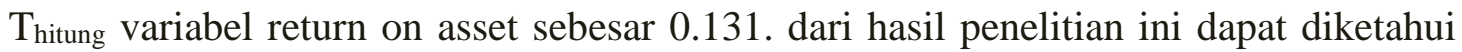
bahwa $\mathrm{T}_{\text {hitung }} 0.131<\mathrm{T}_{\text {tabel }} 1,67528$ yang berarti Ho ditolak dan Ha diterima. Hal ini berarti bahwa return on asset tidak berpengaruh terhadap dividend payout ratio pada perusahaan Real Estate yang terdaftar di Bursa Efek Indonesia periode 2013-2017. Sehingga hipotesis pertama ditolak dan tidak terbukti.

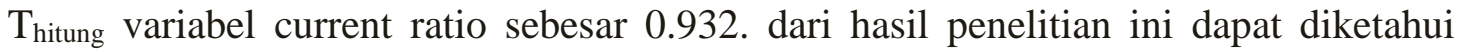
bahwa $\mathrm{T}_{\text {hitung }} 0.932<\mathrm{T}_{\text {tabel }} 1,67528$ yang berarti Ho ditolak dan Ha diterima. Hal ini berarti bahwa current ratio tidak berpengaruh terhadap dividend payout ratio pada perusahaan Real Estate yang terdaftar di Bursa Efek Indonesia periode 2013-2017. Sehingga hipotesis kedua ditolak dan tidak terbukti. 


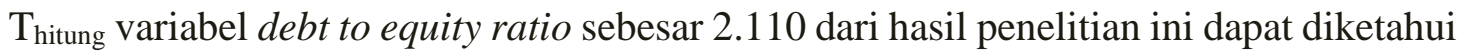
bahwa $\mathrm{T}_{\text {hitung }} 2.110>\mathrm{T}_{\text {tabel }}$ 1,67528 yang berarti Ho diterima dan Ha ditolak. Hal ini berarti bahwa debt to equity ratio berpengaruh terhadap dividend payout ratio pada perusahaan Real Estate yang terdaftar di Bursa Efek Indonesia periode 2013-2017. Sehingga hipotesis ketiga diterima dan terbukti.

Tabel 3

Hasil Uji Koefisien Determinasi

(Adjusted R2)

\begin{tabular}{lcccc}
\hline \multicolumn{4}{c}{ Model Summary } \\
\hline Model & $\mathrm{R}$ & $\mathrm{R}$ Square & $\begin{array}{c}\text { Adjusted } \mathrm{R} \\
\text { Square }\end{array}$ & $\begin{array}{c}\text { Std. Error of the } \\
\text { Estimate }\end{array}$ \\
\hline 1 & $.292^{\mathrm{a}}$ & .085 & .031 & 12.35606 \\
\hline $\begin{array}{l}\text { a. Predictors: (Constant), return on asset, current ratio, debt to equity ratio } \\
\text { b. Dependen Varabel: dividend payout ratio }\end{array}$
\end{tabular}

Pada Tabel 3, terlihat nilai Adjusted $R$ Square sebesar 0,031 atau sebesar 3,1\%. Hal ini menunjukkan bahwa variasi Dividen Payout Ratio dapat dijelaskan oleh variabel return on asset, current ratio dan debt to equity ratio sebesar 3,1\%, sedangkan sisanya 96,9\% (100\%$3,1 \%$ ) dijelaskan oleh variabel lain diluar model.

\section{KESIMPULAN DAN SARAN}

Berdasarkan pembahasan yang telah dilakukan pada bab sebelumnya, maka diperoleh kesimpulan sebagai berikut: (1) Pada uji regresi secara simultan semua variabel bebas yang diteliti return on asset, current ratio dan debt to equity ratio berpengaruh positif terhadap Dividend Payout Ratio pada perusahaan real estate 2013-2017; (2) Pada uji regresi secara parsial atau individu, diantaranya variabel return on asset tidak berpengaruh terhadap dividend payout ratio, variabel current ratio tidak berpengaruh terhadap dividend payout ratio dan variabel debt to equity ratio berpengaruh positif tehadap dividend payout ratio.

Berdasarkan hasil penelitian diatas, maka saran yang dapat diberikan adalah sebagai berikut: (1) Seperti sudah disinggung di atas, nilai koefisien determinasi $\left(\mathrm{R}^{2}\right)$ sebesar 0,259 atau $25,9 \%$ hal ini bermakna bahwa 25,9\% variasi DPR yang bisa dijelaskan oleh variasi dari ketiga variabel bebas yaitu ROA, CR, dan DER sedangkan sisanya sebesar 74,1\% dijelaskan oleh variabel lain yang tidak masuk dalam model. Hal ini mengindikasikan perlunya banyak faktor fundamental yang lain. Bagi peneliti selanjutnya yang tertarik dengan penelitian yang sama diharapkan untuk menambah variabel-variabel lain seperti solvabilitas, free cash flow, firm size, kesempatan investasi dan variabel lainnya yang kemungkinan memiliki pengaruh terhadap kebijakan dividen; (2) Untuk penelitian selanjutnya sebaiknya melakukan penelitian dengan menggunakan jumlah sampel yang lebih besar dan menambah tahun penelitian ataupun memilih subjek yang berbeda. Hal ini dimaksudkan supaya memperoleh hasil penelitian yang lebih baik. 


\section{DAFTAR PUSTAKA}

Anggraini, L.N. (2013). Pengaruh Good Corporate Governance dan Kinerja Keuangan terhadap Kebijakan Dividen pada Perusahaan Manufaktur di Bursa Efek Indonesia Periode 2006-2011. Skripsi, Sekolah Tinggi Ilmu Ekonomi PERBANAS, Surabyaya.

Asril, M. (2009). Leverage terhadap Kebijakan Dividen. Keuangan dan Perbankan, 13(1), $78-87$.

Harahap, S.S. (2009). Analisis Kritis Atas Laporan Keuangan. Jakarta: PT Raja Grafindo Persada.

Kasmir. (2012). Analisis Laporan Keuangan. PT. Grafindo Persada, Jakarta.

Kusuma, R. P. (2018). Pengaruh DAR, Ukuran Perusahaan, Risiko, Pajak, dan Likuiditas terhadap Profitabilitas Perusahaan Sektor Pertambangan di Indonesia. BISMA (Bisnis dan Manajemen), 8(2), 191-203.

Puspaningsih, A., \& Pratiwi, R. G. (2017). Determinan kebijakan dividen di Indonesia: good corporate governance (GCG) sebagai variabel intervening. Jurnal Akuntansi dan Auditing Indonesia, 21(2), 118-129.

Sartono, Agus. (2010). Manajemen Keuangan Teori dan Aplikasi. Yogyakarta: BPFE.

Syamsuddin, L. (2009). Manajemen Keuangan Perusahaan. Jakarta: PT Raja Grafindo Persada. 